\title{
Clinical and mammographic profile of patients with breast cancer surgically treated
}

\author{
Raquel Rodrigues Muradas ${ }^{1 *}$, Maria Teresa Aquino de Campos Velho², Itamar dos Santos Riesgo ${ }^{3}$, Alexandre Duarte Brum4, \\ Raquel Montagner Rossi ${ }^{5}$, Julia Mottecy Piovezan ${ }^{5}$, Melania Lacerda ${ }^{5}$

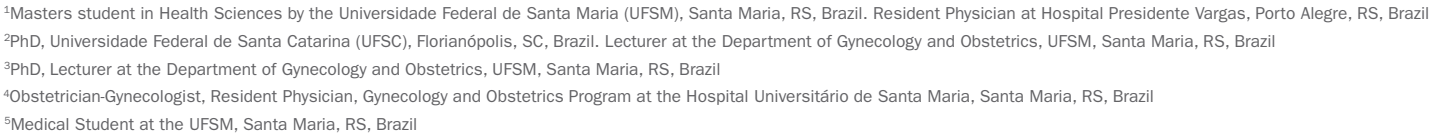

Study conducted at Universidade Federal de Santa Maria - University Hospital of Santa Maria, RS, Brazil

Article received: $7 / 6 / 2014$ Accepted for publication: $7 / 14 / 2014$

*Correspondence: Address: Av. Roraima, s/n, Prédio 22 Camobi Santa Maria, RS Postal code: $97105-900$ rakellm@msn.com

http://dx.doi.org/10.1590/1806-9282.61.03.220

Financial support: Scientific Initiation Scholarship and Research Support Program, PROIC-HUSM. Three scientific initiation scholarships were offered to the medical students who participated in this study. Conflict of interest: none

\section{SUMMARY}

Objective: to analyze the epidemiological, clinical and mammographic profile of women with breast cancer who were treated at the mastology clinic of the University Hospital of Santa Maria and who underwent breast surgery between January 2007 and December 2012.

Methods: this was a cross-sectional study, approved by the Ethics in Research Committee. A review of the patients' medical records was performed. The data were then exported to a software program for statistical analysis, namely Minitab 14.1.

Results: the patients' profile indicated that they were mostly born and raised in Santa Maria (respectively $11.1 \%, \mathrm{n}=16$, and $26.3 \%, \mathrm{n}=68$ ). They were about 55.6 years old $(\mathrm{SD} \pm 12.3)$, white $(90.2 \%, \mathrm{n}=213)$, had already given birth and breastfed their children, were nonsmokers, but also overweight (average BMI of $27 \mathrm{~kg} / \mathrm{m}^{2}$ ). On physical examination of the first medical consultation, these patients, as described in the records: had a palpable mass $(81.1 \%, \mathrm{n}=184)$ measuring over three centimeters, located in the left breast, precisely in the upper outer quadrant (41.4\%, $\mathrm{n}=81)$. Mammography $(39 \%, \mathrm{n}=109)$ showed that this lump was classified as BI$\operatorname{RADS}^{\circledast} 5(40 \%, n=81)$. On histopathological examination, the lump was diagnosed as an invasive ductal cancer $(71.1 \%, \mathrm{n}=191)$. Surgery was generally a radical mastectomy $(84.7 \%, \mathrm{n}=236)$ with axillary dissection $(92.5 \%, \mathrm{n}=222)$.

Conclusion: some of the epidemiological, clinical and mammographic features mentioned above resembled those found in the literature reviewed. However, these patients had advanced disease and underwent non conservative surgical procedures.

Keywords: women's health, breast neoplasm's, health profile, descriptive epidemiology, mastectomy.

\section{INTRODUCTION}

Currently, female breast malignancies are the second cause of cancer in Brazil, according to data from the National Cancer Institute (INCA, 2012). It is the main cause of cancer among women. Every year, approximately $22 \%$ of the new cases of cancer in women are breast cancers. ${ }^{1,3,4}$ The incidence and mortality statistics for breast cancer only do not exceed those of lung carcinoma, which is the most common cancer in the world. ${ }^{1,2}$

According to the World Health Organization (WHO), in the 1960s and 70s, there was an increase of ten times in incidence rates adjusted for age in the population-based cancer registries from several continents. ${ }^{1,3}$

In the world population, the median survival after five years of diagnosis is $61 \%$, while in developed countries the number increases to $73 \%$. In developing countries, median survival after 5 years of diagnosis is close to $57 \%{ }^{1}$ Some authors attribute this fact to the difficulty of early cancer detection. ${ }^{5}$ It is known that the prognosis of breast malignancy is relatively good, if diagnosed and treated in time. ${ }^{6}$

Risk factors related to female reproductive life (early menarche, nulliparity, first pregnancy to term after 30 
years, late menopause and hormone replacement) are well established as elements linked to the development of breast cancer.?

The fact that genetic factors are also associated with increased risk of developing the disease is likewise important. Women with mutations in BRCA1 (Breast Cancer Susceptibility Gene 1) and BRCA2 (Breast Cancer Susceptibility Gene 2) have $85 \%$ chance of developing breast cancer before 70 years of age. ${ }^{6,8}$ As for protective factors, breastfeeding, physical activity and healthy eating to maintain proper body weight are associated with a lower risk of developing this cancer. ${ }^{9}$

Primary prevention of breast cancer is not fully possible due to changes in risk factors, and genetic characteristics that are involved in the etiology. ${ }^{1,3,6}$ So far, mammography for women aged 50 to 69 years is recommended as an effective method for early disease detection. ${ }^{1,6,10}$

The University Hospital of Santa Maria (HUSM) is located in central Rio Grande do Sul and is a reference hospital in the region for oncologic surgeries, with outpatient and inpatient care in various specialties, also being a referral center for other forty nine cities.

Thus, knowing the sociodemographic, clinical and mammographic profile of women seeking care in HUSM for cancer diagnosis and treatment is justified. This research aimed to identify aspects of the disease and the treatment of patients with breast cancer undergoing surgery at HUSM.

\section{Methods}

This work aimed to develop a prevalence study (descriptive, transversal and quantitative), made through a review of the medical records of patients submitted to surgical procedures for the treatment of breast cancer (segmentectomy, lumpectomy, quadrantectomy and mastectomy) at HUSM in a period of six years, from January 2007 to December 2012.

We selected records with data from women diagnosed with breast cancer treated at the HUSM Mastology Service and who underwent surgical procedures in the above period.

First, the authors asked the Medical Records and Statistics Service (SAME) of HUSM to present all the records of female patients treated in the mastology outpatient clinic during the research period. 380 records were obtained. Of this total, the authors disregarded the medical records of 39 patients who died; 31 with surgery performed at other services, cities or hospitals; 20 who did not undergo surgery and were treated medically; five records that were not found after three attempts; and six who were operated (lumpectomy) due to other pathologies besides breast cancer.

After compliance with the exclusion criteria, 279 records were reviewed and, through them, socio-demographic and medical data of the study population were obtained. Then, the information was entered into the Minitab for Windows statistics software - version 14.1 - for descriptive statistical analysis.

Data collection was performed between March and July 2013 after project approval by the Research Ethics Committee of the Federal University of Santa Maria (UFSM) filed as CAAE 13291313.8.0000.5346. In addition, the identity data of the women were kept confidential and all other provisions recommended by Resolution 466/12, approved in December 2012 by the National Health Council, were followed.

\section{Results}

Analyzing the data gathered from the database, the average age of the women included in the study was 55.6 years ( $\mathrm{SD} \pm 12.3$ ), being the youngest patient 20 years old and the oldest, 91 years old. The mean age at menarche and menopause were respectively 13 years $(\mathrm{SD} \pm 1.8)$ and 46.5 years $(\mathrm{SD} \pm 9.2)$ (Table 1$)$.

\begin{tabular}{|c|c|c|c|}
\hline Variables & $N$ & Mean & SD \\
\hline Age (years) & 279 & 55.6 & 12.3 \\
\hline Menarche (years) & 245 & 13.0 & 1.8 \\
\hline Menopause (years) & 142 & 46.5 & 9.2 \\
\hline Smokers & 45 & & \\
\hline Cigarettes/day & 37 & 10.7 & 8.5 \\
\hline Time as a smoker (years) & 30 & 23.4 & 13.4 \\
\hline Race & $\mathrm{N}$ & & $\%$ \\
\hline White & 213 & & 90.2 \\
\hline Black & 9 & & 3.8 \\
\hline Mixed & 14 & & 5.9 \\
\hline BMI & 102 & 27.0 & 4.8 \\
\hline
\end{tabular}

$\mathrm{N}$ : number; SD: standard deviation; BMI: body mass index

It was also found that $86 \%(n=240)$ of these patients gave birth at least once, and $14 \%(n=39)$ were nulliparous. Those who became pregnant had on average three pregnancies and the mothers breastfed their babies in $62.1 \%$ $(n=149)$ of the cases. According to data found in the 
medical records, the patients reported to the doctor that they became pregnant with their first child on average at the age of 23 years $(\mathrm{SD} \pm 5.6)$, and the duration of breastfeeding in the sum of pregnancies was, on average, 20 months $(\mathrm{SD} \pm 12)$. Twenty five patients reported using contraception at the first gynecological consultation described in their records, and only four patients used hormone therapy, representing respectively $8.9 \%$ and 1.4\% (Table 1).

Also as part of the sociodemographic review, with respect to skin color, $90.2 \%(n=213)$ of patients said they were white, $6 \%(n=14)$ were mixed race, and $4 \%(n=9)$ African descendants. The smokers, $24 \%(\mathrm{n}=67)$, smoked for an average of 23 years, at least 10 cigarettes/day. At diagnosis and treatment of breast cancer, women weighed an average of 68 kilos, with a body mass index (BMI) of $27 \mathrm{~kg} /$ $\mathrm{m}^{2}$ (Table 1).

It is known that family history of breast cancer is an important risk factor for cancer. Thus, in this study, the authors found that $37 \%(n=103)$ of patients had a firstdegree relative with breast cancer, and 9.8\% $(n=27)$ reported having a first degree relative with cancer in other reproductive organ (vulvar, vaginal, cervical, endometrial or ovarian cancer).

In the first consultation, as described in the outpatient medical record, $81.1 \%(\mathrm{n}=184)$ of patients had a palpable mass on breast examination; $3.5 \%(\mathrm{n}=8)$ had an ulcerated lesion; and $15 \%(\mathrm{n}=34)$ showed no abnormality on physical examination. The association of nodular and ulcerated lesion was present in one patient only $(0.4 \%)$. The authors found that $41.7 \%(n=81)$ of the lumps were located in the upper outer quadrant. Of these lumps, $49.5 \%(n=96)$ were in the left breast, $47.8 \%(\mathrm{n}=93)$ in the right breast, and only $2.7 \%(n=5)$ of the women had bilateral deformation when inspected. $50.7 \%(n=98)$ of the palpable lumps measured more than three centimeters, as shown in the description of the physical examinations (Table 2).

In the review of the 279 charts, more mammogram results were found, which are shown in Table 2. Of 199 mammograms described in the records, classifications according to the Breast Imaging Reporting and Data System (BI-RADS ${ }^{\circledR}$ ) and mentioned in written were: $40 \%$ BIRADS 5; 33\% BI-RADS 4; and 13\% BI-RADS 0 (zero). Only one patient had a BI-RADS category 6 on mammography. Out of the mammograms described as BI-RADS 4 and 5 , the image of a lump was present in $79.7 \%(\mathrm{n}=158)$, while microcalcifications were reported in $18.2 \%(n=36)$ of the expert opinions, and the combination of lump and microcalcifications was seen in $2.1 \%(n=5)$ of the results.

\begin{tabular}{|c|c|c|}
\hline Variables & $\mathbf{N}$ & $\%$ \\
\hline \multicolumn{3}{|l|}{ Breast lump } \\
\hline Palpable & 184 & 81.1 \\
\hline Ulcerated & 8 & 3.5 \\
\hline Palpable and ulcerated & 1 & 0.4 \\
\hline No changes in the physical examination of breasts & 34 & 15.0 \\
\hline \multicolumn{3}{|l|}{ Size } \\
\hline$\geq 3 \mathrm{~cm}$ & 96 & 49.3 \\
\hline$<3 \mathrm{~cm}$ & 98 & 50.7 \\
\hline
\end{tabular}

Mammographic classification

\begin{tabular}{lll}
\hline BI-RADS zero & 27 & 13.5 \\
\hline BI-RADS 1 & 5 & 2.51 \\
\hline BI-RADS 2 & 8 & 5.5 \\
\hline BI-RADS 3 & 11 & 4.0 \\
\hline BI-RADS 4 & 66 & 33.1 \\
\hline BI-RADS 5 & 81 & 40.7 \\
\hline BI-RADS 6 & 1 & 0.5 \\
\hline
\end{tabular}

N: number; \%: percentage; cm: centimeter; BI-RADS: Breast Imaging Reporting and Data System.

In medical appointments after diagnosis of breast cancer, 97.6\% ( $n=272$ ) of the 279 patients underwent three additional tests (bone scintigraphy, total abdominal ultrasound and chest X-ray), totaling 652 tests for breast cancer staging in the period assessed. Only $5.7 \%(n=16)$ of patients underwent $\mathrm{CT}$ scan after the three additional tests, for more information. Through these staging tests, doctors were able to diagnose probable metastases in $30.1 \%(n=84)$ of patients. Of these, $45.2 \%(n=38)$ were bone metastases, $31 \%(\mathrm{n}=26)$, liver, $15.5 \%(\mathrm{n}=13)$ lung, and only $8.3 \%(n=7)$ were brain metastases (Table 3 ).

As seen in Table 3 regarding type of surgical procedure performed at HUSM, radical mastectomy represented $84.7 \%$ ( $n=236$ ) of the cases. Segmentectomy, quadrantectomy and lumpectomy were performed in $9.3 \%(\mathrm{n}=24)$, $2.1 \%(n=5)$ and $1.1 \%(n=3)$ of the patients, respectively. Mastectomy associated with breast reconstruction in a single surgical event was performed in $2.9 \%$ of patients $(n=7)$. The authors also noted that $92.5 \%(n=222)$ of the procedures were axillary dissections, and only $4.8 \%(n=11)$ were sentinel lymph node dissections.

The postoperative pathological findings in the medical records showed that $71.1 \%(\mathrm{n}=191)$ of tumors were invasive ductal carcinomas; $7.2 \%(n=20)$ were single ductal carcinomas in situ; $5 \%(\mathrm{n}=14)$ lobular carcinomas; and $0.7 \%(\mathrm{n}=2)$ of the patients had a combination of these 
two last histological types. Other histological types, cited in Table 3, were found in the pathological examination of the surgical specimens, namely: mucinous in $3.2 \%$ $(\mathrm{n}=9)$; papillary in $9.6 \%(\mathrm{n}=27) ; 1.4 \%(\mathrm{n}=4)$ of sarcoma; $0.4 \%$ $(n=1)$ cases of tubular carcinoma; and also $0.4 \%(n=1)$ cases of Paget's disease.

TABLE 3 Numerical and percentage description of the surgical treatment of 279 patients with breast cancer, from the central region of the state of Rio Grande do Sul, Brazil.

\begin{tabular}{|c|c|c|}
\hline Variables & $\mathbf{N}$ & $\%$ \\
\hline \multicolumn{3}{|l|}{ Type of surgery } \\
\hline Radical mastectomy & 236 & 84.6 \\
\hline Segmentectomy & 26 & 9.3 \\
\hline Quadrantectomy & 6 & 2.1 \\
\hline Lumpectomy & 3 & 1.1 \\
\hline Mastectomy with breast reconstruction & 8 & 2.9 \\
\hline \multicolumn{3}{|l|}{ Lymphnode } \\
\hline With axillary lymphnode dissection/LND & 222 & 95.2 \\
\hline With sentinel lymphnodebiopsy & 11 & 4.8 \\
\hline \multicolumn{3}{|l|}{ Histological type } \\
\hline Invasive ductal & 191 & 71.1 \\
\hline In situ ductal (single) & 20 & 7.2 \\
\hline Lobular & 14 & 5.0 \\
\hline Ductal and lobular (combined) & 2 & 0.7 \\
\hline Mucinous & 9 & 3.2 \\
\hline Papillary & 27 & 9.6 \\
\hline Sarcoma & 4 & 1.4 \\
\hline Paget & 1 & 0.4 \\
\hline Tubular & 1 & 0.4 \\
\hline \multicolumn{3}{|l|}{ Tumor grade } \\
\hline I/Low & 25 & 11.6 \\
\hline II/Moderate/Intermediate & 148 & 68.8 \\
\hline III/High & 42 & 19.5 \\
\hline
\end{tabular}

$\mathrm{N}$ : number; \%: percentage; LND: axillary lymph node dissection.

With respect to immunohistochemical (IHC) studies, the authors noted that $77.8 \%(\mathrm{n}=182)$ were positive for estrogen receptors and $22.2 \%(n=52)$ were negative. IHC for progesterone receptors revealed $61.5 \%(\mathrm{n}=157)$ of positive results and $38.5 \%(\mathrm{n}=98)$, negative. Markers for c-erbB-2/Her2, were negative in $63 \%(\mathrm{n}=145)$, weak/moderately positive in $19 \%$ $(\mathrm{n}=44)$, and strongly positive in $17.8 \%(\mathrm{n}=41)$.

\section{Discussion}

The therapeutic approach of breast cancer involves surgery, chemotherapy, radiotherapy, hormone therapy, and professional and psychosocial support for the women af- fected and their families. Usually, treatments combine two or more approaches, since individual characteristics, clinical, psychological or social in nature, are also considered. The goal is to achieve better quality of life for women during treatment and survival. ${ }^{6,9}$

While analyzing some of the demographic, gynecological and obstetric information of the women in this study, the authors found that the mean age (55.6 years) at the time of the first visit to the mastology clinic - with diagnosis suggestive of breast cancer - was similar to those of other Brazilian references. ${ }^{1,4,11}$

Relatively rare before 35 years, age is an important risk factor, especially around 50 years. ${ }^{1}$ Incidence increases rapidly until the age of 50 , and after that, the increase is slower. This behavioral change in relation to age is known in the literature as "Clemmesens hook", and has been attributed to menopause. ${ }^{12}$

The age of menarche was generally 13 years and menopause, 46. These are important aspects that, at first, would be regarded as risk factors for breast cancer. However, in contrast, the literature indicates that the frequency is higher in women with early menarche and late menopause. ${ }^{1,3,13}$ The average age of menarche in girls in southern Brazil is close to 12 years, ${ }^{14}$ while menopause usually occurs at $48 .^{15}$

Regarding obstetric history, the authors found that most had three pregnancies and breastfed for a total period of twenty months, including all pregnancies. Pregnancy and breastfeeding are considered protective factors against breast cancer. ${ }^{9}$ In this study, however, the authors noted that, although no test in this respect has been conducted, these elements did not seem to play a protective role against the disease. It is possible that, in this study, the genetic factor had a greater effect as $37 \%(n=103)$ of the medical records showed that the patients mentioned a first-degree relative with breast cancer. A positive family history of breast cancer is one of the main elements related to the development of the disease. ${ }^{7,16}$

These facts support the need for strong, consistent and permanent education programs for women, especially those with risk factors for the disease. Debunking myths, working with the truth, reinforcing and insisting on health education can represent a significant trigger to modify behaviors leading to personal physical integrity and self-care, and to achieve goals of early diagnosis, which unfortunately seem not to have occurred in the study population.

In addition, the authors found based on the average BMI that most women were overweight (BMI $=27 \mathrm{~kg} / \mathrm{m}^{2}$ $\mathrm{SD} \pm 4.8$ ), which is also associated with the development of malignancies of the breast. Unlike cervical cancer, malig- 
nant breast tumors are related, according to the literature, with the urbanization process, showing an increased risk of disease among women with higher socioeconomic status, overweight or obese, and physically inactive. ${ }^{16,17}$ Thus, the protective factors are opposed to these lifestyle habits and women should be encouraged and educated to promote health towards the development of better eating habits and physical exercise to maintain appropriate body weight. ${ }^{16,17}$

In the clinical evaluation, it was clear that most patients already on their first visit to the mastology outpatient clinic had tumors of significant sizes, that is, three centimeters on average. This leads to a delayed diagnostic reasoning considering tumor size, and impoverishes the prognosis and quality of milder treatments. The results found were similar to those in the national literature, indicating that the reality of our setting is not far from others, at least in Brazil. ${ }^{18-20}$

Although being considered a cancer with relatively good prognosis if diagnosed and treated in time, breast cancer mortality rates remain high in Brazil, probably because the disease is still diagnosed in advanced stages. ${ }^{1}$ Worldwide, the average survival rate after five years is $61 \%$, while in developed countries the number reaches $73 \%$ and in developing countries, $57 \% .^{1,3,4}$

Clinical breast examination remains an important aid in the active detection of breast cancer. ${ }^{16}$ This examination must be performed insistently among women of population groups considered at high risk for breast cancer (family history of breast cancer in first-degree relatives, and others), at least annually for women aged 40 to 49 years. ${ }^{4,7,21}$ Nevertheless, a piece of information found in the research draws attention: $15 \%(n=34)$ of all women studied - with histopathological diagnosis of breast cancer -, did not have changes in the physical examination of their breasts, according to the medical records.

In Santa Maria, 39\% ( $n=109)$ of patients in first consultation at the mastology outpatient clinic bring with them the results of a previously performed mammogram. During the review of the medical records, 199 more of these tests were found, which was key because the authors could see that $18.2 \%(n=36)$ of mammograms classified as BIRADS 4 or 5 showed only microcalcifications and the patients had no palpable nodules. This highlights the importance of mammography as a screening radiographic examination of non palpable breast tumors.

The Brazilian National Cancer Institute, INCA, estimated that mammography coverage in 15 cities of Brazil and the Federal District ranged between 37 and 76\% in the year 2002-2003. ${ }^{9,22}$ As seen in this publication, the fact that mammograms are not widely performed can ex- plain the late diagnosis and high mortality rates still observed in the country. ${ }^{3,9}$ Considering that $62 \%$ of women in Southeastern Brazil older than 60 years have never undergone a mammogram, it is clear that we need to pay attention to these women, first through screening. ${ }^{23,24}$ As a matter of fact, screening should also be prioritized in the region of Santa Maria.

The method necessary to continue the treatment of patients, in addition to the mandatory staging tests, is called histopathology. As expected, the histological type of breast tumor most prevalent in this study was invasive ductal $71.1 \%(\mathrm{n}=191)$. These numbers are in agreement with the literature. ${ }^{17,18}$ After the diagnosis, surgical techniques for the treatment of the disease include both conservative and radical, with axillary lymphadenectomy. ${ }^{25}$ The surgical technique of choice is determined according to histological type and tumor size, breast size, experience and preference of the surgeon, age and choice of the patient and also the standardized treatment protocols of the service. ${ }^{25}$

It has been mentioned that most of the patients at HUSM had a palpable mass, larger than three centimeters and located in the left breast. Thus, most of them underwent radical mastectomy. Conservative surgery was predominantly used in cases with initial staging at diagnosis, and accounted for only $12.5 \%(\mathrm{n}=35)$ of patients. These aspects will be discussed below.

Modified radical mastectomy is the removal of the mammary gland and axillary lymph node dissection, preserving both pectoral muscles. ${ }^{26}$ This procedure is indicated in the following preferred conditions: presence of $3 \mathrm{~cm}$ or larger tumors, not attached to the muscle; in patients with recurrence after conservative treatment; patients with any conditions that may render them ineligible for conservative treatment or those who do not agree to preserve the breast. ${ }^{26}$ In this study, the authors found that $84.7 \%(n=236)$ of the women who had their treatment in HUSM underwent this type of surgery. This suggests the presence of more advanced stages of the disease, and thus worse prognosis. These data are corroborated by the literature, since the percentages found are similar to those seen in Santa Maria. ${ }^{1,3,4}$

As for conservative surgery in the treatment of breast cancer, we emphasize that it can be performed in several ways. Quadrantectomy and lumpectomy are the most common techniques. They differ depending on the amount of glandular tissue removed and the safety margin associated to the tumor. ${ }^{27}$ During the study period, only $2.1 \%$ $(n=6)$ and $1.1 \%(n=3)$ of the patients in this study perform quadrantectomy and lumpectomy, respectively. 
Conservative surgery is well accepted due to the minimization of damage caused by surgery. However, it depends on early diagnosis, which is linked to educational and socio-economic factors among women, and efficiency of health services as a whole. Effort will be needed for us to have patients in the near future with less advanced tumors treated at the HUSM mastology service.

A therapeutic measure still very much discussed is that of axillary dissection, a surgical procedure considered physically limiting, especially for women who use their arms as a working tool. ${ }^{28}$ The results of the study showed that axillary dissection was the technique used in $92.5 \%$ ( $n=222)$ of the surgical procedures, which points out that the Santa Maria service treated patients in more advanced stages of the disease.

Since it was founded, in 1970, the HUSM is one of the few hospitals located in central Rio Grande do Sul that treats exclusively patients from the Brazilian Unified Health System, SUS. It is, therefore, a reference for clinical, surgical and oncological treatment of both inpatient and outpatient admissions, caring for women with breast cancer in the central part of southern Brazil. ${ }^{29}$

\section{Conclusion}

The negative findings of the study concerned the authors of this research. They did not expect the results to be so alarming. We know that measures have been taken to improve care for women with breast cancer at HUSM and the mastology service. The institution has sought, in addition to providing a more ethical and effective care to patients, to comply with Law $\mathrm{N}^{\circ} 12.732 / 2012$, in force since May 2013, which establishes that patients with malignant cancer are entitled to undergo treatment at SUS within up to 60 days from the date of diagnosis confirmation through pathology report or a lesser period, depending on the therapeutic necessity as seen in the medical records.

Study limitations include the fact that any research that is developed based on data gathered from medical records - often poorly written - may fail to collect important information missing in the documents.

\section{ACKNOWLEDGMENTS}

We thank the Scientific Initiation Scholarship and Research Support Program at PROIC-HUSM.

\section{Resumo}

Perfil clínico e mamográfico das pacientes com câncer de mama, tratadas cirurgicamente.
Objetivo: analisar o perfil epidemiológico, clínico e mamográfico de mulheres com câncer de mama atendidas no ambulatório de mastologia do Hospital Universitário de Santa Maria (UFSM) e submetidas à cirurgia de mama no período de janeiro de 2007 a dezembro de 2012.

Método: estudo de prevalência realizado de modo transversal, após ter sido aprovado pelo Comitê de Ética em Pesquisa. Foram realizadas revisões dos prontuários das pacientes. As informações obtidas foram transpassadas para um programa de análise estatístico, o Minitab 14.1. Resultados: o perfil das pacientes, encontrado no estudo, mostrou que elas eram, na maioria, naturais ou procedentes de Santa Maria (respectivamente 11,1\%, $n=16$, e 26,3\%, $\mathrm{n}=68)$. Elas tinham 55,6 anos ( $\mathrm{DP} \pm 12,3)$, eram brancas $(90,2 \%, n=213)$, gestaram, amamentaram, não eram tabagistas, mas estavam com sobrepeso (IMC médio de $27 \mathrm{~kg}$ / $\mathrm{m}^{2}$ ). No exame físico do primeiro atendimento, essas pacientes, conforme descrito no prontuário, tinham nódulo palpável $(81,1 \%, \mathrm{n}=184)$ com mais de $3 \mathrm{~cm}$ na mama esquerda, precisamente no quadrante lateral superior $(41,4 \%$, $\mathrm{n}=81)$. Na mamografia $(39 \%, \mathrm{n}=109)$, esse nódulo foi classificado como BI-RADS ${ }^{\circledR} 5(40 \%, \mathrm{n}=81)$. No exame histopatológico, o nódulo foi diagnosticado como câncer do tipo ductal invasor $(71,1 \%, \mathrm{n}=191)$. A cirurgia foi, em geral, uma mastectomia radical $(84,7 \%, n=236)$ com esvaziamento axilar $(92,5 \%, \mathrm{n}=222)$.

Conclusão: concluiu-se que algumas das características epidemiológicas, clínicas e mamográficas citadas acima assemelharam-se com a literatura revisada. No entanto, essas pacientes apresentavam câncer de mama em estádio avançado e foram submetidas a uma técnica cirúrgica não conservadora.

Palavras-chave: saúde da mulher, neoplasias da mama, perfil de saúde, epidemiologia descritiva, mastectomia.

\section{References}

1. INCA. Estimativa 2010: incidência de câncer no Brasil. Instituto Nacional de Câncer. - Rio de Janeiro: INCA; 2009.

2. Ferlay J, Shin HR, Bray F, Forman D, Mathers C, Parkin DM, et al. Estimates of worldwide burden of cancer in 2008: Globocan 2008. Int J Cancer. 2010;127(12):2893-917.

3. INCA. Estimativas 2008: incidência de câncer no Brasil. Brasil. Ministério da Saúde. Secretaria de Atenção à Saúde. Instituto Nacional de Câncer. Coordenação de Prevenção e Vigilância de Câncer. Rio de Janeiro: INCA; 2007.

4. INCA. Controle do câncer de mama: documento de consenso. Instituto Nacional de Câncer (INCA). Rio de Janeiro: INCA; Ministério da Saúde; 2004

5. Souza A, Andrade AN. "Corpos marcados e fé na vida..." Mastectomia e Políticas Públicas de Saúde da Mulher. Rev Psicol Política. 2008;8(5):157-78.

6. INCA. Instituto Nacional de Câncer José Alencar Gomes da Silva. Coordenação Geral de Ações Estratégicas. Coordenação de Prevenção e Vigilância. Estimativa 2012: incidência de câncer no Brasil. Rio de Janeiro: INCA; 2011. 
7. Silva PA da, Riul SS. Câncer de mama: fatores de risco e detecção precoce. Rev Bras Enferm (Brasília). 2011;64(6):1016-21.

8. Maluf MFM, Mori JL, Barros ACDS. Planejamento familiar em mulheres de alto risco de câncer de mama. Rev Bras Cancerol. 2008;54(4):359-65.

9. Thuler LC. Considerações sobre a prevenção do câncer de mama feminino. Rev Bras Cancerol. 2003;49(4):227-38.

10. Bim CR, Pelloso SM, Carvalho MDB, Previdelli ITS. Diagnóstico precoce do câncer de mama e colo uterino em mulheres do município de Guarapuava, PR, Brasil. Rev Esc Enferm USP. 2010;44(4):940-6.

11. Agência Nacional de Saúde Suplementar (Brasil). Manual técnico de promoção da saúde e prevenção de riscos e doenças na saúde suplementar Agência Nacional de Saúde Suplementar. Rio de Janeiro: ANS; 2006.

12. Hakama $M$. The peculiar age specific incidence curve for cancer of the breast: Clemmesens hook. Acta Pathol Microbiol Scand. 1969;75(3):370-4.

13. Smeltzer SC, Bare BG. Brunner \& Suddarth: tratado de enfermagem médicocirúrgica. $9^{\text {a }}$ ed. Rio de Janeiro: Guanabara Koogan; 2005.

14. Horta RL, Santos I. Idade da menarca em Pelotas: estudo piloto. Rev AMRIGS. 1991;35(2):83-7.

15. Pedro AO, Pinto Neto AM, Paiva LHSC, Osis MJ, Hard E, Idade de ocorrência da menopausa natural em mulheres brasileiras: resultados de um inquérito populacional domiciliar. Cad Saúde Pública. 2003;19(1):7-25.

16. INCA/MS, 2002. Prevenção e Controle de Câncer. Rev Bras Cancerol. 2002;48(3):317-32.

17. NCA/MS - Instituto Nacional do Câncer/Ministério da Saúde. Estimativa 2012: incidência de câncer no Brasil. Rio de Janeiro: INCA; 2012.

18. Moraes AB, Zanini RR, Turchiello MS, Riboldi J, Medeiros LR. Estudo da sobrevida de pacientes com câncer de mama atendidas no hospital da Universidade Federal de Santa Maria, Rio Grande do Sul, Brasil. Cad Saúde Pública. 2006;22(10):2219-28.

19. Pinheiro AB, Lauter DS, Medeiros GC, Cardozo IR, Menezes LM, Souza RMB, et al. Câncer de mama em mulheres jovens: análise de 12.689 Casos. Rev Bras Cancerol. 2013;59(3):351-9.
20. Borges JBR, Soriano PM, Barros N, Souza AZ, Barros ACD, Cerri GG, et al. Avaliação por Doppler colorido do carcinoma da mama: correlação com dados clínicos e histopatológicos. Radiol Bras. 2004;37(5):323-8.

21. Brasil. Ministério da Saúde. Plano de ação para o controle dos cânceres do colo do útero e da mama 2005-2007. Diretrizes Estratégicas Ministério Da Saúde. Brasília (DF): Ministério da Saúde; 2005.

22. Brasil. Ministério da Saúde. Secretaria de Vigilância em Saúde. Secretaria de Atenção à Saúde. Instituto Nacional de Câncer. Coordenação de Prevenção e Vigilância. Inquérito domiciliar sobre comportamentos de risco e morbidade referida de doenças e agravos não transmissíveis: Brasil, 15 capitais e Distrito Federal, 2002-2003. Rio de Janeiro: INCA; 2004.

23. Instituto Brasileiro de Geografia e Estatística (IBGE). Diretoria e Pesquisa. Departamento de População e Indicadores Sociais. População residente Censo 2000: Brasil, Unidades da Federação e Municípios, 2000. Available at: http://www.ibge.gov.br/.

24. Departamento de Informática do SUS. Informações de saúde. Estatísticas vitais-mortalidade e nascidos vivos. Available at: http://www.datasus.gov.br.

25. Alves PC, Silva APS, Santos MCL, Fernandes AFC. Conhecimento e expectativas de mulheres no pré-operatório da mastectomia. Rev Esc Enferm USP. 2010;44(4):989-95.

26. Franco J, Santos R, Castro K, Malfacini S, Santoro C. Tratamento cirúrgico do câncer de mama. In: Franco J. Mastologia-formação do especialista. Rio de Janeiro: Atheneu; 1997.

27. Souza GA. Cirurgia no câncer de mama: tratamento radical $x$ tratamento conservador. Femina. 1999;27(7):587-9.

28. Gonçalves SRDOS, Arrais FMA, Fernandes AFC. As implicações da mastectomia no cotidiano de um grupo de mulheres. Rev Rene. 2007;8(2):9-17.

29. Censo Populacional 2011. Instituto Brasileiro de Geografia e Estatística (IBGE). Available at: http://www.ibge.gov. 